\title{
Detection of Hepatitis C Virus (HCV) RNA among Young Adult Drug Users
}

\author{
Azza H. El. Salakawy \\ Department of Microbiology, Faculty of Medicine for \\ Girls, Al-Azhar University
}

A study to determine the frequency and potential risk factors of hepatitis $\mathrm{C}$ virus (HCV) infection was carried out on 33 serum samples from drug users; admitted to hospital for treatment. Sera were screened for HCV antibodies (anti-HCV) using enzyme-linked immunosorbent assay (ELISA). Anti-HCV antibodies were detected in $11 / 33(33.3 \%)$ of drug users versus $2 / 30(6.7 \%)$ of volunteer blood donors (control group), which represent statistically significant changes $(p<0.001)$. HCV-RNA was detected by one step nested reverse transcription polymerase chain reaction (RT-PCR). HCV-RNA was detected in 7/11 (63.6\%) of seropositive drug users, all of them were injection drug users.

There was significant association of $\mathrm{HCV}$ infection with age and injection drug use $(p<0.05)$. However, there was no significant relation between the duration of drug abuse and $\mathrm{HCV}$ infection. From these findings, I conclude that HCV infections are common among injection drug users probably due to the intravenous use of drugs.

\section{Introduction}

An estimated 170 million people worldwide have hepatitis $\mathrm{C}$ virus (HCV) infection (WHO, 1997). $\mathrm{HCV}$ is a major cause of parenterally transmitted acute hepatitis (Choo et al., 1989). It is an enveloped positive stranded RNA virus in the family Flaviviridae, its genome consists of 9.600 nucleotides which encodes of $>$ 3.000 amino acids that is processed into structural (S) and nonstructural (NS) proteins (Kolykhalov et al., 1997). It is an important cause of chronic hepatitis and may eventually cause progressive liver disease, cirrhosis, and liver cancer (Alter et al, 1992; Tong et al, 1995).
In Egypt, there is high prevalence of hepatitis C virus, where $10 \%-20 \%$ of the general population is infected (Kamel et al 1992; Darwish et al, 1993). As in other regions of the world, in Egypt some $\mathrm{HCV}$ infections are caused by transfusions (Khalifa et al, 1993; Abdel-Wahab et al, 1994), injection drug use (Bassily et al., 1995), perinatal expossure (kumar et al,1997) and percutaneous medical procedures (both traditional and non traditional).

$\mathrm{HCV}$ is widely spread among injecting drug users (IDUs) (van den Hoek et al., 1990; Thomas et al, 1997). The most common mode of HCV 


\section{Detection of Hepatitis C Virus}

transmission among IDUs seems to be the multiperson use of contaminated syringes (Alter,1997). Surveys of adult, long-term IDUs in the United States consistently report seroprevalence levels of $70 \%-90 \%$ (Kelen et al, 1992), signifying that $\mathrm{HCV}$ infection has reached saturation levels in this population (Zeldis et al, 1992).

The aim of this study is to assess the incidence of $\mathrm{HCV}$ infection by the detection of both anti-viral antibodies and viral genomes in serum samples of drug users.

\section{Material and Methods \\ Study Subjects:}

Thirty-three serum specimens were obtained from drug users who were admitted to Al-Khanka Hospital, Qalyubiyia Governorate for treatment. All subjects were males with median age 24.73 (19-30 years). Sixteen of them $(48.5 \%)$ were injecting drug users (IDUs).

\section{Control group:}

Thirty age-matched volunteer blood donors with no history of drug use, were selected from blood bank of Benha University Hospital. Study subjects and control group sera were kept at $-50^{\circ} \mathrm{C}$ until tested.

\section{Detection of anti-HCV antibodies by ELISA:}

Sera were screened for anti- HCV $\operatorname{IgG}$ by enzyme immunoassay commercial kit (Murex, version 4.0) which utilises antigens from the putative core (C, structural), NS3 protease / helicase (non- structural), NS4 (non - structural) and NS5 replicase (non- structural) regions of the virus. The assay was done according to the manufacturer's instructions.

\section{Extraction of RNA:}

RNA was extracted from sera by QIAmp viral RNA mini spin kit (Qiagen, Ltd, UK) as recommended by the manufacturer.

\section{Reverse-transcription polymerase chain reaction (RT-PCR)}

Seropositive sera from addicts and controls were subjected to HCV-RNA detection. RT-PCR was performed in one step by using QIAGEN One Step RT-PCR kit (Qiagen Ltd, UK) in accordance with the instructions supplied with the kit.

PCR was used in a nested configuration in two steps using 2 sets of primers derived from the 5, untranslated region ( $5^{\prime} \mathrm{UT}$ ) which is the conserved region among different $\mathrm{HCV}$ isolates (Han et al, 1991). These primers were supplied by Sorin Biomedica, Italy. The outer primers were $1 \mathrm{CH}$ antisense primer (from 1-21) 5'-G GTGCACGGTCTACGAGACCTC-3', and $2 \mathrm{CH}$ sense primer (from 289269)5'-AACTACTGTCTTCACGCAG AA-3'. The inner primers were 1TS anti-sense (from 70-90) 5'-GCGACCC AACACTACTCGGCT-3', and 4CH sense primer (from 257-240) 5' - ATGG CGTTAGTATGAGTG-3'.

The RT-PCR was performed as followed. The reaction consisted of $10 \mu l$ of $5 x$ Qiagen One Step buffer, $10 \mu \mathrm{l}$ of $10 \mathrm{x}$ Q solution, $40 \mathrm{mM}$ dNTPs 
mixture $(10 \mathrm{mM}$ each of dATP, dCTP, dGTP and dTTP), 50 pmol of each of outer primers, $2 \mu \mathrm{l}$ of RT-PCR enzyme mix contained reverse transcriptase and Taq polymerase enzymes, RNase inhibitor and template RNA then complete to $50 \mu \mathrm{l}$ by RNase-free water.

The program of RT-PCR was: $48^{\circ} \mathrm{C}$ for $45 \mathrm{~min}$ and $95^{\circ} \mathrm{C}$ for $5 \mathrm{~min}$ for one cycle then $94^{\circ} \mathrm{C}$ for $1 \mathrm{~min}, 55^{\circ} \mathrm{C}$ for $1 \mathrm{~min}, 72^{\circ} \mathrm{C}$ for $1 \mathrm{~min}$ for 30 cycles then extension at $72^{\circ} \mathrm{C}$ for $7 \mathrm{~min}$ in thermocycler (Biometra).

The second amplification was performed in total $50 \mu \mathrm{l}$ reaction consisted of $5 \mu$ of10X Taq polymerase buffer, $1 \mu \mathrm{l}$ of dNTPs mixture, $2 \mathrm{U}$ of Taq polymerase enzyme (Promega, UK), 50 pmol of each primer of inner primers and $5 \mu$ from $1^{\text {st }}$ PCR product and complete the volume to $50 \mu$ by sterile dist. water. The program was: $95^{\circ} \mathrm{C}$ for $5 \mathrm{~min}$ then 30 cycles of $94^{\circ} \mathrm{C}$ for $1 \mathrm{~min}, 55^{\circ} \mathrm{C}$ for $1 \mathrm{~min}$ and $72^{\circ} \mathrm{Cfor}$ $1 \mathrm{~min}$, then final extension at $72^{\circ} \mathrm{C}$ for 7 min for one cycle. PCR products of 187-bp were analyzed by $2 \%$ agarose gel electrophoresis. Bands was stained with ethidium bromide and visualized by UV transilluminator.

Proper precutions were followed such as negative control, aerosolresistant-tips, separate processing areas were used to minimize the risk of amplicon contamination, RNase resistant glasswares and plasticwares to prevent RNA degradation.

\section{Statistical analysis:}

Proportions were compared by the $x^{2}$ test or Fisher's exact test, a $P$ value of $\quad<.05$ was considered significant.

\section{Results}

Detection of anti- HCV antibodies:

Among 33 drug users 11 had antibodies to $\mathrm{HCV}(33.3 \%)$ versus $2 / 30$ among control subjects $(6.7 \%)$ with statistically significant $(p<0.001)$ difference (Table $1)$.

Sixteen of the 33 drug users (48.49\%) were injection drug users (IDUs). HCV antibodies were detected in 9/16 $(56.25 \%)$ of IDUs. There is significant ( $p=0.012$ ) increase of HCV infection with age while, there were no correlation $(P=0.496)$ with duration of drug abuse. HCV seropositivity was significantlly ( $p=0.009$ ) associated with intravenous drug use (Table 2).

Of the HCV seropositive addicts, 2/11 (18.2\%) injected heroin alone, $7 / 11$ (63.6\%) used heroin in combination with other drugs e.g. morphine, hashish, bango, narcotics, alcohol and amphetamine derivatives $2 / 11 \quad(18.2 \%)$ used bango in combination with other drugs.

\section{Detection of HCV-RNA:}

HCV-RNA was detected by RT-PCR in $7 / 11(63.6 \%)$ of seropositive drug users while, there was no signal of nucleic acid in the two seropositive controls (Table 1; Figure 1). All these seven addicts used the intravenous route. 


\section{Detection of Hepatitis C Virus}

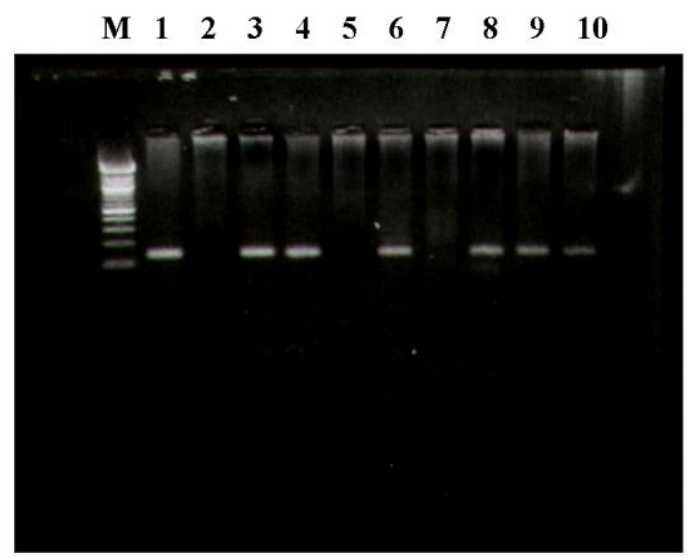

Fig. (1): Agarose gel electrophoresis of RT- PCR amplification products of HCV-RNA, M:

100bp marker, positive samples (lanes: $1,3,4,6,8,9$ and 10 ) with amplicon 187 bp.

Table (1). HCV seropositivity and viraemia among drug users versus controls

\begin{tabular}{|l|ll|lc|l|}
\hline & \multicolumn{2}{|l|l|l|}{ Drug users n = 33 } & \multicolumn{2}{l|}{ Controls n =30 } & $P$ value \\
\hline Anti-HCV antibodies & $11 / 33$ & $(33.3)$ & $2 / 30$ & $(63.7)$ & $P<0.001(\mathrm{~S})$ \\
\hline HCV- RNA & $7 / 11$ & $(63.6)$ & $0 / 2$ & 0 & \\
\hline
\end{tabular}

$\mathrm{S}=$ significant; $\mathrm{n}=$ number; percentage in parenthesis

Table (2) Correlation between HCV seropositivity and risk factors in drug users

\begin{tabular}{|c|c|c|c|c|c|}
\hline Variable & HC & sitive & HCV & gative & $P$ value \\
\hline - Age in years: & $\mathrm{n}$ & $\%$ & $\mathrm{n}$ & $\%$ & \multirow{5}{*}{$\begin{array}{r}0.012 \\
(\mathrm{~S})\end{array}$} \\
\hline I: $19-21$ & 1 & 9.1 & 7 & 31.8 & \\
\hline II: $22-24$ & 1 & 9.1 & 8 & 36.4 & \\
\hline III: $25-28$ & 4 & 36.4 & 4 & 18.2 & \\
\hline IV: $29-30$ & 5 & 45.5 & 3 & 13.6 & \\
\hline \multicolumn{5}{|l|}{$\begin{array}{l}\text { - Duration of drug use } \\
\text { in months: }\end{array}$} & \multirow{5}{*}{$\begin{array}{l}0.496 \\
\text { (N.S.) }\end{array}$} \\
\hline I: $2-24$ & 2 & 18.2 & 5 & 22.7 & \\
\hline II: $25-48$ & 1 & 9.1 & 5 & 22.7 & \\
\hline III: $49-72$ & 5 & 45.5 & 7 & 31.8 & \\
\hline IV: $73-240$ & 3 & 27.3 & 5 & 22.7 & \\
\hline \multicolumn{5}{|l|}{$\begin{array}{l}\text { - Route of administr- } \\
\text { ation: }\end{array}$} & \multirow{3}{*}{$\begin{array}{l}0.009 \\
(\mathrm{~S})\end{array}$} \\
\hline Intravenous (I.V) & 9 & 81.8 & 7 & 31.8 & \\
\hline$*$ Other routes & 2 & 18.2 & 15 & 68.2 & \\
\hline
\end{tabular}

$\mathrm{n}=$ number; $\mathrm{S}=$ significant; N.S. = non significant; $*$ other routes e.g. oral, smoking and snuffing . 


\section{Discussion}

In this study, HCV antibodies were detected in $33.3 \%$ of drug users who are at very high risk of hepatitis $\mathrm{C}$ infection, and parenteral drug abuse may be one cause of this increased risk. Sixteen of them were injection drug users (IDUs), nine of them $(56.25 \%)$ had HCV antibodies.

Bassily et al, (1995) performed a study on HCV infection in paid professional blood donors, the antibodies were found in $26.6 \%$ of them versus $6 \%$ of controls. Attia and coworkers (1996) reported $27 \%$ seroprevalence of anti-HCV among paid blood donors and $17 \%$ in unpaid blood donors. However, van den Hoek et al, (1990) reported HCV seropositivity in74\% IDUs in Amsterdam, and Esteban et al, (1989) reported 70\% among IDUs in Spain. Rezza et al, (1996), found antibodies in $63 \%$ of Italian IDUs. Trišler et al, (1999) detected $\mathrm{HCV}$ infection in $52 \%$ of Slovenian IDUs and in $68.6 \%$ of Croatian IDUs.

In the present study, the prevalence of $\mathrm{HCV}$ infection in drug abusers is lower than American and European countries, inspite of high prevalence of $\mathrm{HCV}$ among general population (10\%-20\%) (Kamel et al., 1992; Darwish et al., 1993 ). This may be due to: first parenteral drug abuse is not known to be common in Egypt (Bassily et al., 1995). Second, the age of drug users in the present study ranged from 19-30 years. This age group has low HCV prevalence which was reported by Darwish et al,(1992) who found $6 \%$ positivity among 20 to 30 years old volunteer blood donors which is comparable with control group $(6.7 \%)$ in the present study. However, the $\mathrm{HCV}$ prevalence in drug users is higher than that reported by Thorpe and others (2000). They found HCV antibodies in $27 \%$ of American IDUs of the same age sector.

The risk factors for $\mathrm{HCV}$ infection in the present study are similar to those previously reported by other authors. There are statistically significant association between the age and injection route of drug use. This is in agreement with Rezza et al, (1996), Thomas et al (1997) and Thorpe et al,( 2000 )results. However, they also found significant relation of duration of injecting drugs and increase $\mathrm{HCV}$ seropositivity. But, in the present study the duration had no significant association, it may be due to the small sample size of my study, because most of addicts were not cooperative. As well as the parenteral drug abuse is not very common in Egypt. That is noticed in this study, where 16/33 (48.5\%) of addicts practised injecting drugs besides oral, smoking and snuffing routes, which is in agreement with Bassily et al,(1995).

In the present work, HCV-RNA was detected in $7 / 11(63.6 \%)$ of anti$\mathrm{HCV}$ positive addicts all of them were injecting drug users. The incidence of RT-PCR positivity in anti-HCV positive individuals varied in different reports from 25\% (MacDonald et al, 1994) to 100\% (Peterlli et al, 1994). François and coworkers (1993) found that the 


\section{Detection of Hepatitis C Virus}

prevalence of HCV-RNA were $25.9 \%$ in $\mathrm{HCV}$ antibody-positive blood donors, $66.6 \%$ in IDUs and $92 \%$ in haemophiliacs. Ray et al, (2000) detected HCV-RNA in $64 \%$ of sera obtained from high titer seropositive blood donors throughout Egypt. However, Hassaballa \& Hegazi (1994), detected HCV nucleic acid in $33 \%$ of HCV seropositive apparently healthy individuals applying work abroad. Gawish and Arafat (1996) detected HCV-RNA in 20/40 (50\%) of chronic hepatitis patients.

The high incidence of viraemia reported in the present study among drug users especially who practised parenteral use indicates high infectivity and they may have a dangerous role of infection among addicts who shared syringes or even in community.

Since HCV infection, which results in chronic disease in more than $50 \%$ of cases (Alter, 1997) represents an important public health problem.

\section{References}

Abdel-Wahab, M.F., Zakaria, S., Kamel, M., Abdel- Khaliq, M.K., Mabrouk, M.A., Salama, H., Esmat, G., Thomas, D.L. and Strickland, G.T. High seroprevalence of hepatitis $\mathrm{C}$ infection among risk groups in Egypt. Am. J. Trop. Med. Hyg. 1994; 51: 563-567.

Alter, M.J. Epidemeology of hepatitis C. Hepatology 1997; 26 ( Suppl 1): 62S-65S.

Alter, M.J., Margolis, H.S., Krawczynski, K., Judson, F.N., Mares, A., Alexander, W.J., Hu, P.Y., Miller,
J.K., Gerber, M.A., Sampliner, R.E., Meeks, E.I. and Beach, M.J. The natural history of community aquired hepatitis C in the United States. N. Engl.J. Med. 1992; 327: 1899-1905.

Attia, M.A.M., Zekri, A.N., Goudsmit J. Boom, R., Khaled H.M., Mansour M.T., De Wolf F., Alam El-Din H.M., and Sol, C.J.Diverse patterns of recognition of hepatitis $\mathrm{C}$ virus core and nonstructural antigens by antibodies present in Egyptian cancer patients and blood donors. J. Clin. Microbiol. 1996; 34: 2665-2669.

Bassily, S., Hyams, K.C., Fouad, R.A., Samaan, M.D. and Hibbs, R.G. A high risk of hepatitis $\mathrm{C}$ infection among Egyptian blood donors: the role of parenteral drug abuse. Am. J. Trop. Med. Hyg. 1995; 52 : 503-505.

Choo, Q.L., Kuo, L., Weiner A.J., Overby, L.R., Bradley D.W., and Houghton.M. Isolation of cDNA clone derived from a blood - borne non- A, non-B viral hepatitis genome. Science 1989; 244: 359-361.

Darwish, M.A., Raouf, T.A., Rushdy, P., Constantine, N.T., Rao, M.R., and Edelman, R. Risk factors associated with a high seroprevalence of hepatitis $\mathrm{C}$ virus infection in Egyptian blood donors. J. Clin. Microbiol. 1993; 29: 551-556.

Darwish, N.M., Abbas, M.O., Abdelfattah, F.M. and Darwish, M.A. Hepatitis $\mathrm{C}$ infection in blood donors in Egypt. J. Egypt. Pub. Health Ass. 1992; 68: 223-236.

Esteban, J.I., Viladomiu, L., Gonzalez, A., Roget, M., Genesca, J., Esteban, R., Lopez- Talavera, J.C., Hernandez, J.M., 
Vargas, V., Buti, M. and Guardi M. Hepatitis $\mathrm{C}$ virus antibodies among risk groups in Spain. Lancet 1989; ii: 294297.

François, M., Dubois, F., Brand, D., Bacq, Y., Guerois, C., Mouchet, C., Tichet, J., Goudeau, A. and Barin F. Prevalence and significance of hepatitis $\mathrm{C}$ virus (HCV) viraemia in $\mathrm{HCV}$ antibody-positive subjects from various populations. J.Clin. Microbiol. 1993; 31: 1189-1193.

Gawish, A and Arafat, M.A. Third generation ELISA (ELISA-3) versus recombinant immunoblot (RIBA) and polymerase chain reaction (PCR) in diagnosis of hepatitis $\mathrm{C}$ virus infections. Egypt. J. Med. Microbiol. 1996; 5: 217 222.

Han, J.H., Shyawala, V., Richman, K.H. et al., Characterization of the terminal region of hepatitis $\mathrm{C}$ viral RNA: identification of conserved sequences in the 5' untranslated region and poly (A) tails at the 3' end. Proc. Natl. Acad. Sci. USA 1991; 88: 17111715.

Hassaballa, M.A. and Hegazi L.A. Prevalence of antibodies to $\mathrm{HCV}$ in Egypt. A survey of 5221 apparently healthy individuals. Egypt. J. Int. Med. 1994; 3: 369-382.

Kamel, M.A., Ghaffar Y.A., Wasef, M.A., Wright, M., Clark L,.C. and Miller, F.D. High HCV prevalence in Egyptian blood donors. Lancet 1992; 340: 427.

Kelen, G.D., Green, G.B., Purcell R.H. Hepatitis B and hepatitis C in emergency department patients. N. Engl. J. Med. 1992; 326: 1399-1404.
Khalifa, A.S., Mitchell, B.S., Watts, D.M. Prevalence of hepatitis C viral antibody in transfused and nontransfused Egyptian children. Am. J. Trop. Med. Hyg. 1993; 49: 316-321.

Kolykhalov, A.A., Agapov, E.V., Blight, K.J., Mihalik, K., Feinstone, S.M. and Rice, C.M. Transmission of hepatitis $\mathrm{C}$ by intrahepatic inoculation with transcribed RNA. Science 1997; 277: 570-574.

Kumar, R.M. Frossad, P.M., and Hughes, P.F. Seroprevalence and mother -to- infant transmission of hepatitis $\mathrm{C}$ in asymptomatic Egyptian women. Eur. J. Obstet. Gynecol. Reprod. Biol. 1997; 75: 177-182.

MacDonald, K.L., Mills, W.A., Wood, R.C. et al., Evaluation of clinical and laboratory aspects of antibody tests for detection of hepatitis $\mathrm{C}$ virus infection in blood donors and recipients from a low risk population. Transfusion. 1994; 34: 202-211.

Petrelli, E., Manzin, A., Paolucci, S. et al.,. Chronic liver disease and active hepatitis $\mathrm{C}$ infection in patients with antibodies to this virus. J. Clin. Pathol. 1994; 47: 148-152.

Ray, S.C., Arthur R.R., Carella, A., Bukh, J. and Thomas, D.L. Genetic epidemiology of hepatitis $\mathrm{C}$ virus throughout Egypt. J. Inf. Dis. 2000; 182: 698-707.

Rezza, G., Sagliocca, L., Zaccarelli, M., Nespoli, M., Siconolfi M. and Baldassarre C. Incidence rate and risk factors for $\mathrm{HCV}$ seroconversion among injecting drug users in an area with low HIV seroprevalence. Scand. J. Infect. Dis. 1996; 25: 27-29. 


\section{Detection of Hepatitis C Virus}

Thomas, D.L., Nakatsuji, Y., Shih, J.W., Alter, H.J., Nelson K.E., Astemborski, J. A. et al. Persistence and clinical significance of hepatitis $G$ virus infections in injecting drug users. J. Infect. Dis. 1997; 176: 586-592.

Thorpe, L.E., Ouellet, L. J., Levy J.R., Williams I.T. and Monterroso E.R. Hepatitis C virus injection: Prevalence, risk factors, and prevention opportunities among young infection drug users in Chicago, 1997-199. J. Inf. Dis. 2000; 182: 1588-1594.

Tong, M.J., El-Farra, N.S., Reikes, A.R, and Co, RL. Clinical outcomes after transfusion- associated hepatitis C. N. Engl. J. Med. 1995; 332: 1463 1466.

Trišler, Z. Seme, K., Poljak, M., Čelan-Lucu, B. and Sakoman, S.
Prevalence of hepatitis $\mathrm{C}$ and $\mathrm{G}$ virus infections among intravenous drug users in Slovenia and Croatia. Scand. J. Infect Dis. 1999; 31: 33-35.

van den Hoek, J.A.R., van Haastrecht, H.J.A., Goudsmit, J., de Wolf, F. and Coutinho, R.A. Prevalence, incidence, and risk factors of hepatitis $\mathrm{C}$ virus infection among drug users in Amsterdam. J. Inf. Dis. 1990; 162: 823826.

World Health Organization. Hepatitis C: global prevalence. Wkly Epidemiol. Rec. 1997; 72: 341-348.

Zeldis, J.B., Jain, S., Kuramoto, I.K. et al. Seroepidemiology of viral infections among intravenous drug users in northern California. West. J. Med. 1992; 156: 30-35.

\section{الكشف عن الحمض النووى الريبوزى لفيروس الالتهاب الكبدى (س) فى المدمنين الشباب الريبري لفيروي

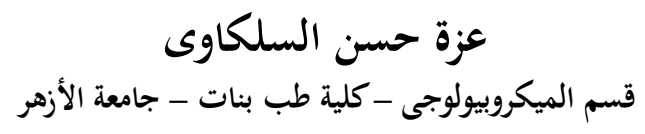

أجريت هذه الدراسة على أمصال 33 شاب مدمن تتراوح أعمارهم من (19 : 30 عاماً) أدخلوا

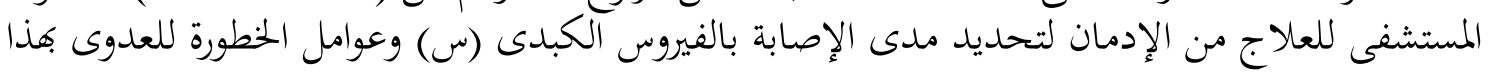
الفيروس. وجدات الاجسام المضادة للفيروس باستخدام الجيل الرابع لاختبار الاليزا في أمصال 11 من هؤلاء

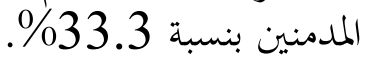

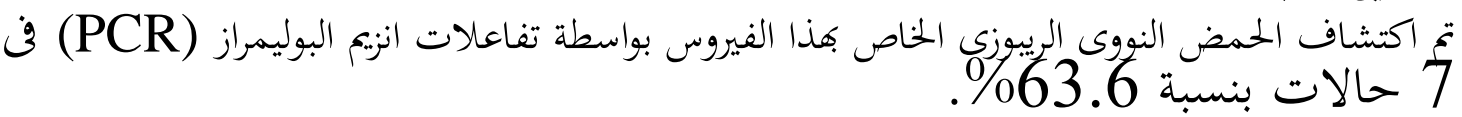

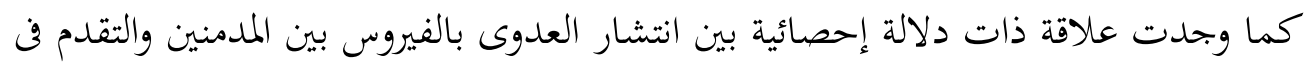

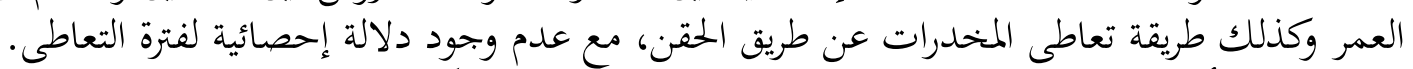

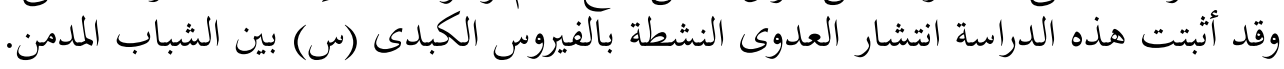

